\title{
Attraction of investments as the main factor in the development of the macroregion siberia
}

\author{
Oleg Repinskiy ${ }^{1, *}$, Maria Gubanischeva ${ }^{2}$ and Natalya Romaneskul ${ }^{2}$ \\ ${ }^{1}$ Irkutsk National Research Technical University, 664074 Irkutsk, Russia \\ ${ }^{2}$ Tomsk State University of Architecture and Building, 634003 Tomsk, Russia
}

\begin{abstract}
The macroregion Siberia possess large reserves of natural resources, which makes it possible to create a modern high-tech infrastructure for their extraction and processing. The production of final products in this region can become a driving force for the development of the Russian economy in the medium and long term. Unlocking the potential of Siberia and the Far East requires significant investments comparable to the money spent by the USSR for the development of Western Siberia, the North, the Arctic and the construction of the BAM (the Baikal-Amur Mainline). The volume of public investment is insufficient for the dynamic development of the region, so to obtain additional investment funds stimulation of the private sector of the economy is required. Potential investors have the sufficient financial resources, but it is necessary to improve an investment climate in Russia. It will allow the country to attract the maximum amount of money. To improve the investment climate one should make significant changes in the management, legal, banking and other aspects of business activity in Russia.
\end{abstract}

\section{Introduction}

Recently, the Government of the Russian Federation has been paying special attention to the development of Siberia and the Far East. Now, the federal and regional authorities have adopted a significant amount of important documents defining tasks and mechanisms aimed at the development of Siberia and the Far East. For example, the socio-economic development strategy of the Far East and the Baikal Region up to 2025 approved by the Government of Russia in 2009. In accordance with characteristics of the territories under consideration given by the strategy the main problems hindering their development are economic and infrastructural isolation from the rest of Russia, the poor quality of internal transport links between the territories combined with their huge sizes, the focal model of settlements with low population density, agriculture in unfavorable climatic conditions, the high cost and seasonal nature of cargo delivery for the Arctic and northern regions of the Far East.

\footnotetext{
*Corresponding author: $\underline{\text { repin80@mail.ru }}$
} 
Nevertheless, one should note that the region also has a number of competitive advantages. Primarily it is an economic and geographical location (first of all, the shortest East - West transport routes) in the Asia-Pacific region, huge reserves of natural resources, long land and water borders as opportunities for socio-economic cooperation, developed seaport infrastructure, attractive tourist sites. To improve the economic performance of the region the strategy provides implementation, among other things, of investment projects concerning the electric power industry and the transport infrastructure of the Far East aimed at improving transport accessibility, capacity of the Baikal-Amur Mainline and the TransSiberian Railway, improving the quality of transport and logistics services and integration into international transport and logistics systems.

\section{Research methodology}

GDP's and other economic indicators' fall occurs due to a significant drop in oil prices and decline in export earnings. The recession of 2020 in the world and in Russia led to the fact that economic activity was blocked by the restrictions imposed due to the pandemic.

The pandemic has become a shock to the global economy, it led to the significant reduction of manufacturing as well as in activity in the service sector, and broke logistics chains. According to the IMF, by the end of 2020, the global savings rate may decrease slightly ( -0.7 percentage points) and will amount to $23.5 \%$, what can be caused by redistribution of investments between industries, for example, in the health system, education, public administration, as well as by reduction in GDP. All countries in postcoronavirus period will have to adapt to new functional standard in the economy and public life.

According to the IMF, after the crisis of 2008-2009, there was growth in the ratio of investment to GDP in developed countries, where in 2010-2019 the average value of the indicator was $21.5 \%$, while in developing countries, on the contrary, the value of the indicator decreased. As of April 2021, the IMF has raised its estimate of Russia's economic growth for 2021 from 3\% to 3.8\% [1]. Bloomberg has put Russia in second position in its ranking of developing countries in terms of economic prospects for 2021. The top three also included Thailand-1st position and South Korea-3rd one [2]. According to the annual study of the international company EY based on the results of 2020, Russia despite the crisis caused by the pandemic, is still one of the most attractive countries in Europe for foreign investors taking the 11th place in the rating [2]. Russia's main investors are China, Germany and the United States. However, the share of foreign investments in Russia's fixed assets is declining. The volume of foreign investments in the real sector of the Russian economy in 2019 decreased by $25 \%$ compared to 2018 (and in monetary terms by 22.2 billion rubles - from 86.6 to 64.4 billion rubles) [2].

At the same time, foreign capital has a positive impact on the development of the economy, since it:

- ensures access to advanced technologies and modern management methods;

- contributes to the improvement of technologies and increase the level of production;

- leads to an increase in tax revenues, the creation of additional jobs;

- improves the economic image of a country in the world arena, increases degree of confidence in it;

- promotes the integration of the domestic economy into the world economic community.

The surveys conducted show that the main factors for Russian business preventing investment in the renewal of fixed capital are instability of economic situation, the complexity of its forecasting and the insufficient amount of its own funds. 
To coordinate foreign investors' activity expressed a desire to invest in Russian projects, the Russian Investment Agency has been established - a non-profit, non-governmental organization whose main goal is to attract foreign direct investments in the Russian economy. Foreign investments are extremely important, but it is equally important to create favorable conditions for internal investment given by Russian business. Along with its obvious advantages attracting foreign investment has some limitations. Excessive dependence on foreign capital represent a threat to the country's economic security as it makes the economy vulnerable under the influence of the geopolitical situation, does not encourage domestic businesses to invest in the real sector, etc.).

According to S\&P Global Ratings, for January 2021, Russian Federation's rating has retained its position at the lower stage of the investment grade. The sovereign rating of the Russian Federation in foreign currency remained at the level of "BBB -" with a stable outlook.

According to the agency, the current credit rating of Russia (the next revision of the rating is scheduled for July 2021) already takes into account the probability of moderate tightening of sanctions primarily from the United States. The resources and experience of the Russian government including significant financial reserves (the amount of liquid assets of the Sovereign wealth fund exceeds $\$ 116$ billion), allow it to absorb this risk without damage for the credit rating.

In regional context, higher activity remains in the financial and economic centers, investments in the manufacturing industry has increased. According to national rating results, the following regions of Russia are among the top five in terms of investment climate: Moscow, the Republic of Tatarstan, Tyumen Oblast, Tula Oblast, the Republic of Bashkortostan [2]. But it should be noted that as of 2020, on average, investments in fixed assets in all regions of Russia increased by only $1.3 \%$ compared to 2013. [3]. It should also be noted that during economic transformation caused by quarantine restrictions and the forced decline in the activity of many industries the role of companies ' own funds in financing capital investments has increased even more and the role of bank lending has decreased in contrast. As follows from the data of Rosstat, the volume of investments in fixed assets in the Russian Federation in 2020 decreased by $1.4 \%$ compared to 2019 and amounted to 20.118 trillion rubles.

Over the past ten years, the ratio of investment to GDP in Russia has shown significant fluctuations: it exceeded $23.3 \%$ of GDP in 2008, decreased to $17.2 \%$ in 2009, increased to $24.5 \%$ by 2012 . The rapid recovery of Russian investments ended in 2012 . The rate of accumulation in Russia fell to $22.4 \%$ of GDP at the end of 2014, in 2015-2019 the value of the indicator varied in the range 22-23.7\%. In 2020, the IMF estimates that the share of investments in the country's GDP will decrease by 0.2 percentage points compared to 2019 and will amount to $22.9 \%$. IMF experts also predict the recovery of the indicator in 2023 2025 to the pre-crisis level of 2019 despite the fact that the rate of accumulation of fixed capital in Russia in recent years remains at a low level, what is unacceptably for sustainable long-term economic development. .

The best value of the indicator was achieved in 2013 when the gross accumulation of fixed capital amounted to $\$ 500$ billion [3].

The country has faced a situation where having a relatively high rate of gross savings most sectors of the Russian economy except for export-oriented sectors, suffer from the acute shortage of investment resources.

In recent years, the Russian state as an investor has implemented a number of major investment projects in Siberia and the Far East - Integrated development of the Lower Angara region, laying of the Eastern Siberia - Pacific Ocean oil pipeline, construction of facilities for the APEC summit, construction of the Chita - Khabarovsk highway, industrial 
introduction of the SSJ-100 aircraft. According to the rating presented by experts of the Russian Academy of Sciences, the Inaglin GOK (mining and refining plant) in Yakutia, Cosmodrome Vostochny and the Sakhalin GRES-2 are among the top three investment projects in the Far East having done the greatest multiplicative contribution to the development of territories; various programs for the long-term development of the eastern part of the country have been put into effect; the scale of direct and indirect financing of the eastern territories has been increased. Along with increase in the volume of public investment, the set of tools for state participation in investment processes has been significantly expanded - new development institutions, including the Investment Fund, have been created; mechanisms generating special economic zones have been used, procurement and concession legislation has been improved, and mechanisms for program-targeted management of budget investments have been introduced. It is important to understand that the state will not be able to play the role of a key investor in medium term in the context of slowing economic growth and deterioration of the current parameters of the state budget. Private capital does not have a strong wish to invest in Russia. Private capital has been leaving the country since 2008: 2008 - \$ 133.6 billion; 2009 - \$ 57.5 billion; 2010 - \$ 30.8 billion; 2011 - \$ 81.4 billion; 2012 - $\$ 54.6$ billion (Table 1).

Table 1. Net import/export of private capital according to the balance of payments.

\begin{tabular}{|c|c|c|c|c|c|c|}
\hline Years & $\mathbf{2 0 0 7}$ & $\mathbf{2 0 0 8}$ & $\mathbf{2 0 0 9}$ & $\mathbf{2 0 1 0}$ & $\mathbf{2 0 1 1}$ & $\mathbf{2 0 1 2}$ \\
\hline $\begin{array}{c}\text { Net capital import/export } \\
\text { by banks, \$ billion }\end{array}$ & 45.8 & -55.2 & -32.2 & 15.9 & -23.9 & 18.5 \\
\hline $\begin{array}{c}\text { Net import/export of capital } \\
\text { by other sectors, \$ billion }\end{array}$ & 42.0 & -78.3 & -25.3 & -46.7 & -57.4 & -73.1 \\
\hline $\begin{array}{c}\text { Net capital import/export by } \\
\text { private sector, total \$ billion }\end{array}$ & 87.8 & -133.6 & -57.5 & -30.8 & -81.4 & -54.6 \\
\hline
\end{tabular}

An anti-record was set in 2014, when about \$ 159 billion was withdrawn from the country. The current situation looks more optimistic. According to the preliminary estimates of the Central Bank of the Russian Federation the net export of capital from Russia by the private sector in January — March 2021 decreased by $34.81 \%$ compared to the same period last year and amounted to $\$ 11.8$ billion [4]. Many researchers believe that the greatest positive contribution to economic growth is made by investments, especially private sector investments. The author believes that it is necessary to create all conditions for stopping the outflow of private capital and transforming its potential into investments.

According to the data of the World Bank Group and The IMF in 2019 Russia ranked 31st in the ranking of countries in terms of foreign direct investments with $\$ 8.8$ billion. The top three are expected to include the United States - \$258 billion, China - \$ 203 billion and Germany - \$ 105 billion.

Russia is improving its position in the world ranking of countries in terms of business conditions. So, if in 2013 it took the 92nd place, ahead of the BRIC countries: China-96th place, Brazil-116, India-134 (Doing Business - 2014), then in 2020 it took the 28th position (China - 31, India - 63, Brazil - 124, Doing Business-2020).

In 2012, the Agency for Strategic Initiatives launched the National Business Initiative (NPI), which aims to improve the business environment in the country. For the first time entrepreneurs together with representatives of government authorities and the expert community have participated in the creation of road maps (action plan) - a number of actions aimed at simplifying, reducing the cost, and speeding up business procedures. The Russian government has approved 12 such road maps. Over the period of their implementation from 2012 to 2019,893 events were executed, which is 94 percent. To implement the road maps 
505 legal acts including 97 federal laws have been issued [4]. In order to further improve the investment climate and eliminate the shortcomings having arisen during the implementation of the road maps, the Government in 2019 approved the action plan "Transformation of the Business Climate". Thus, the activity in this direction is not finished.

One can underline among the factors worsening the investment climate in Russia as follows -

- poor quality of state institutions;

- controversial and constantly varied legislative framework;

- high level of investment and credit risks;

- lack of investment protection mechanisms as well as product sharing;

- non ideal banking system;

- low level of business services (audit, insurance, consulting, property valuation, legal support);

- inconsistency of Russian accounting system with international financial accounting and reporting standards, etc. [5,6].

Making an investment forecast for the period up to 2030, the Government of the Russian Federation is guided by a conservative scenario. It means that in the next 20 years, the Russian economy will not be able to return to the growth trajectory of 2000-2008, and even maintenance of a lower rate will require significant efforts. Insufficient investment activity will not allow the country to increase the rate of gross fixed capital formation in GDP in 2018-2020 to more than $25 \%[7,8]$.

Significant polarization of the economic space is a special feature of Russia. In the metropolitan areas (Moscow and St. Petersburg), the high level of economic activity remains. Economic growth zones also include resource-producing and metallurgical regions, densely populated regions in the south of the European part of Russia, and seaport regions in the west and south of the country. The situation is quite different in Siberia and the Far East, whose investment attractiveness ratings are deteriorating. None of the regions of Siberia and the Far East got through the group of regions with a high investment rating.

\section{Results of the study}

The development of Siberia and the Far East will require large-scale investments, including state investments in system-forming programs and projects. According to the RAS to ensure the accelerated development of Siberia and the Far East providing the GRP growth rate 1.52.0 percentage points ahead of the national average, it is necessary to invest 16.5 trillion rubles (or $\$ 570$ billion) in the period up to 2030, while state's share of participation ranges from $25 \%$ to $34 \%$.

Investments in the production of oil/gas, mining, road construction equipment, ships, oil/gas production platforms and equipment required for the development of fields in Siberia, in the Far East and in the Arctic shelf are estimated at 16-18 trillion rubles. Obviously that the development of the macroregion Siberia including Western Siberia and the Arctic Shelf will require even more investments. Attracting such large-scale volume of investments from various sources including private Russian and foreign capital is impossible without significant improvement of investment climate, creation of an effective mechanism of economic preferences and benefits for investors, and a special procedure for administrative management of investment processes in Siberia and the Far East $[9,10]$.

The following sectors of the Russian economy are the most promising for attracting national and foreign investment to Siberia and the Far East: 
- extraction of minerals that will be in demand on world markets in the next 15-20 years (hydrocarbons, rare earth metals, etc.);

- construction of mining and processing plants and deep processing enterprises;

- mechanical engineering including the production of oil/gas, mining, road construction equipment, ships, oil/gas production platforms and equipment; transport engineering production of road equipment, electric locomotives, railway wagons, aircraft equipment;

- agricultural and industrial sector;

- creation of global data centers for storing and information processing;

- creation of branches of large software companies, etc.

In the coming years, it will be necessary to attract a wide range of foreign and national investors, whose business models can ensure for Siberia and the Far East significant financial, social and other dividends. The expected deficit of state budget funds requires abandoning the policy of budget sponsorship for significant projects and moving to cost-effective investments.

Among the main problems causing the unsatisfactory state of investment climate in Russia and hindering the inflow of investment, one can distinguish: at the macro level - the unpredictability of national foreign policy and, as a result, economic restrictions introduced in relation to the Russian Federation, the dependence of the main macroeconomic indicators on the export of hydrocarbons, the accumulation of financial flows in the export-raw materials sector to the detriment of the manufacturing industry, the imperfection of legislative regulation of investment business. At the meso-level - the imperfection of regional legislation, the lack of reliable mechanisms protecting the rights of participants in investment projects, corruption in government bodies. At the micro level - excessive cost of credit resources, shortage of high-tech equipment of domestic production in the market, a lack of qualified personnel, and an insufficient quantity of research centers and laboratories.

\section{Discussion of the results}

The critical areas of Russia's investment policy should be:

- diversification of investment sources through the expansion of international cooperation. The key partners investing in the economy of the Siberian regions should be companies not only from China, but also from Japan, South Korea, the USA, the EU, Canada, Australia, etc.;

- creation of a system providing long-term state guarantees and safe investment conditions for foreign and Russian investors, including the introduction of international standards for judicial (and non-judicial) settlement of economic disputes and conflicts;

- reduction of investment risks for Siberia and the Far East, which are significant barriers for national and foreign business;

- attracting reputable Russian and foreign consulting companies, investment funds to determine the investment potential and risks of prospective projects in Siberia and the Far East [11, 12].

To increase the investment attractiveness of the macroregion Siberia, a number of tasks should be solved.

- To develop a system of preferences, benefits and guarantees increasing considerably the investment attractiveness of Siberia and the Far East.

- Create an Investment Map of Siberia and the Far East using modern geoinformation systems, which will remove the information barrier and substantially expand the circle of potential investors. 
- Develop a program to attract investors for the development of new fields, the creation of deep processing enterprises, and the placement of assembly enterprises of heavy and special engineering with subsequent localization of activities.

- Determine the list of priority development areas (PDA), give them a status allowing them to provide tax benefits to foreign and Russian investors operating in these territories; more widely use the mechanism of Production Sharing Agreement (PSA), etc. [13,14].

According to the Center of Economic and Financial Research and Development (CEFIR) at the Russian School of Economics, the main obstacles to business development in the Far East are: underdeveloped transport infrastructure, a shortage of qualified labor, limited access to electricity and high tariffs on it.

\section{Conclusion}

Proposals and measures aimed at improving the investment climate and the transition to investment through stimulation policy

The main goal of the investment policy is to encourage the attraction of real investments and innovation-based entrepreneurs to the economy of Siberia and the Far East. To improve the investment climate and stimulate investment, it is necessary to:

- to reduce the administrative overhead on business and bureaucratic barriers for investors creating new production facilities and enterprises in Siberia and the Far East thereby the cost of projects, implementation time and risks will be reduced;

- to use new, corrected efficiency criterion when making decisions on state support for investment projects and development programs in the macroregion Siberia. The new criterion should take completely into account strategic, geopolitical and social implications, as well as the indirect consequences of projects implementation;

- to create an effective mechanism of economic preferences and benefits for businesses and the population in Siberia and the Far East;

- to integrate most of offered institutional solutions within the framework of a special administrative procedure managing investment processes in Siberia and the Far East.

The first group of proposals and measures (general measures of institutional support for the development of Siberia and the Far East) includes the following steps:

- Regularize the strategic and program documents already developed and are being implemented, and integrate them into a single decision-making administrative system.

- Adopt the Strategy for the Development of Siberia and the Far East for the period up to 2050 and the State Program for the Development of Siberia and the Far East until 2030, agreed with the Strategy for the socio-economic Development of the Far East and the Baikal Region for the period up to 2025, the accelerated scenario for the long-term socio-economic development of Russia until 2030.

- To approve the list of priority investment projects for implementation in Siberia and the Far East on the terms of public-private partnership. Create a system for monitoring, evaluating and controlling their implementation.

- Expand the circle of parameters to include major investment projects in state programs at the federal and interregional levels and in projects of federal development institutions.

To implement the second group of measures related to the regulatory framework, it is necessary to:

- Adopt legislative acts ensuring state control and regulation of transfer pricing practices in vertically integrated companies in order to bring the territorial structure of production volumes, value added and tax deductions into line.

Adopt legislative acts regulating the practice of providing state guarantees in lending to companies involved in the implementation of large infrastructure and innovative projects, as 
well as partial reimbursement for transport, agriculture and small businesses of interest paid on bank loans and leasing payments.

- Make changes to the tax and customs legislation in order to improve the investment climate and support the implementation of new investment projects.

- To amend the migration legislation in order to provide large investment projects with labor resources.

\section{References}

1. China Lags as Thailand, Russia Rank Top Emerging Market Picks, https://www.bloomberg.com/graphics/2020-emerging-markets-recovery-ranking/

2. Investicii $\mathrm{v}$ nefinansovye aktivy. Rosstat, https:// www.gks/ru/investment_nonfinancial?print=1

3. Investicionnaya privlekatel'nost' stran Evropy za 2020 god: Rossiya, https://www.ey.com/ru_ru/attractiveness/21/european-attractiveness-survey-2021russia

4. CHistyj ottok kapitala iz RF za I kvartal 2021, https://www.finversia.ru/news/markets/chistyi-ottok-kapitala-iz-rf-za-i-kvartal-2021goda-snizilsya-na-34-8-do-11-8-mlrd-93385

5. A. Bovkun, I. Korodyuk, Conf. Ser.: Mat. Sc. and Eng., 667, (2019)

6. S. Zakharov, A. Bovkun, K. Vasiliev, Intern. Conf. Quality Man., Trans. and Inf. Sec., Inf. Techn., 32, (2017)

7. Y. Barykina, IOP Conf. Ser.: Mat. Sc. and Eng., 667, (2019)

8. V. Konyuhov, A. Gladkih, R. Zott, A J. of Phys.: Conf. Ser., 1582, (2020)

9. A. Gladkih, V. Konyuhov, I. Galyautdinov, E. Shchadova, IOP Conf. Ser.: Mater. Sci. Eng., 760, (2020)

10. A. Dykusova, E. Golovina, IOP Conf. Ser.: Mat. Sc. And Eng., 667, (2019)

11. S. Zakharov, A. Troshina, A. Lobova, Intern. Conf. Quality Man., Trans. and Inf. Sec., Inf. Techn., 601, (2017)

12. A. Basova, A. Nechaev, World Appl. Sci. J., 1544, (2013)

13. A. Nechaev, S. Zakharov, A.Troshina, Intern. Conf. Quality Man., Trans. and Inf. Sec., Inf. Techn., 552, (2017)

14. A. Nechaev, D. Ognev, O. Antipina, Intern. Conf. Quality Man., Trans. and Inf. Sec., Inf. Techn., 548, (2017) 